\title{
Health Sector Governance: An Overview of the Legal and Institutional Framework in Bangladesh
}

\author{
MD Parvez Sattar \\ Department of Law, School of Liberal Arts and Social Sciences, Independent University, Bangladesh, Dhaka, Bangladesh \\ Email: rana@iub.edu.bd, ranapsattar@gmail.com
}

How to cite this paper: Sattar, M. P. (2021). Health Sector Governance: An Overview of the Legal and Institutional Framework in Bangladesh. Open Journal of Social Sciences, 9, 395-414. https://doi.org/10.4236/jss.2021.911027

Received: October 22, 2021

Accepted: November 27, 2021

Published: November 30, 2021

Copyright (อ 2021 by author(s) and Scientific Research Publishing Inc. This work is licensed under the Creative Commons Attribution International License (CC BY 4.0).

http://creativecommons.org/licenses/by/4.0/

\section{(c) (i) Open Access}

\begin{abstract}
The on-going COVID-19 outbreak has unveiled the inadequacy, inefficiency, mismanagement and deeply ingrained poor governance in the healthcare system of many national jurisdictions. In addressing these drawbacks and challenges, the present article examines the organizational structure of the healthcare sector in Bangladesh with a specific focus on its legal, policy and regulatory frameworks. Background information and data used in the article are mostly derived from desk-based analysis of health sector institutional studies and media reports as both primary and secondary sources as well as reviewing scholarly texts and commentaries relating to health sector governance in Bangladesh. Accordingly, from a critical analysis of an assortment of facts, thoughts and speculations it has been noted that the health sector of the country has been long struggling due to challenges emanating from deficient national policy priorities, absence of dynamic stewardship and effective planning and management, high inequity and low quality in service delivery, lack and abuse of resources, widespread corruption, inadequacy of health professionals and urban centred service structure, among others. In addition to mapping out a coherent and comprehensive legal and regulatory framework for the nation's healthcare system, a key recommendation of the paper is on devising short, intermediate and long-term plans and policies in coordination with other relevant sectors and agencies-both public and private-ensuring optimum accountability, transparency and predictability in reorganising a comprehensive sectoral approach to health service administration and management.
\end{abstract}

\section{Keywords}

Health Governance, Health Sector in Bangladesh, Legal and Institutional Framework, COVID-19 and Health Governance, Health, Law and Human Rights 


\section{Introduction}

Since its independence almost half a century ago, Bangladesh has made great strides in improving its health indicators. Challenges, however, still persist in the sector including high inequity in healthcare financing, with significant gaps between the top and bottom wealth quintiles as well as urban-rural access to resources. There is also a higher concentration of inequality in specific geographic areas such as Haor wetlands (a wetland ecosystem in the north-eastern part of Bangladesh), Char lands (sandbars that emerge as islands within the river channel) and urban slums. The key purpose of the present paper is to flesh out the challenges that exist in health service delivery in Bangladesh with specific focus on relevant legal, institutional and governance frameworks.

As observed in an earlier study conducted by the Global Health Workforce Alliance (GHWA), major challenges in the health sector of Bangladesh include "an overly-centralized health system, weak governance structure and regulatory framework, weak management and institutional capacity in the Ministry of Health and Family Welfare (MoHFW), fragmented public service delivery, inefficient allocation of public resources, lack of regulation of the private sector-which employs $58 \%$ of all physicians, shortage of $\mathrm{HRH}$, high turnover and absenteeism of health workers, and poor maintenance of health facilities and medical equipment" (WHO, 2021). With regard to the legal and regulatory framework, it is further noted that "[W]hile there exist a number of Acts and Ordinances to regulate the health system, including regulation of different types of providers, practice facilities and NGOs, many of these legal instruments date from several decades ago" (Ahmed et al., 2015: p. 25).

There are further challenges within the health system including the ambiguities between the Ministry of Health and Family Welfare (MoHFW) and the Ministry of Local Government, Rural Development and Co-operatives (MoLGRDC) regarding the roles and responsibilities for urban health. While public sector health service quality is poor and often inaccessible, the private sector facilities are largely unregulated. All these drawbacks and loopholes in the healthcare administration and services are further aggravated by endemic corruption, irregularities and abuse of the resources and institutional capacities leading to weak governance in this crucial sector of the country (Govindaraj et al., 2018). The issue of healthcare governance has particularly emerged as a major national and global attention on the face of the on-going COVID-19 pandemic that started in Bangladesh in March 2020.

In the stated backdrop, the present paper undertakes a synoptic analysis of existing policy, regulatory and management frameworks administering the health sector in Bangladesh. At the outset, in the first section below, a brief overview of the healthcare system focuses on service delivery structures and administration of sector-based programmes and priorities. It has been observed that the cost of services in private health facilities is unaffordable to many. In fact, out-of-pocket health expenditure paid by individuals in Bangladesh is the highest in South Asia 
that stands at 67 percent of the country's total health costs (Molla, 2021).

A particular attention has been given in the following parts to the roles and responsibilities of concerned institutions and agencies-both public and private-including in particular the key sector agency mandated for health administration-the Directorate General for Health Services (DGHS)-operating under the MoHFW. Highlighting the roles of other related government agencies, this section also discusses the various service providers and facilities in the private sector. These include the country's ever growing private clinics and diagnostic centres, NGO provided health, family planning and nutrition services as well as roles of various professional groups and international development partners. Based on these analyses, key challenges of healthcare governance in Bangladesh have been highlighted.

The next section focuses on the policy and legal frameworks relating to the sector followed by major regulatory issues and challenges encountered. This part of the discussion places specific attention on the legal and institutional challenges and constraints including implementation of existing laws and regulations, concerned government agencies' inter and intra-departmental coordination, distribution and delegation of roles and responsibilities, etc. Based on the review and analysis, the paper makes a number of general as well as specific recommendations for reforming the healthcare system in Bangladesh emphasising on both institutional and regulatory reforms as well as on meaningful political commitments, equitable resource allocation and accountable management as well as increased professionalism in service provisions. The paper concludes with a note that in order to implement and sustain any reforms undertaken, a comprehensive, revised health policy remains a priority for ensuring a transparent, accountable, equitable and predictable governance within the overall healthcare mechanism of the country.

\section{Healthcare Sector in Bangladesh at a Glance}

Located in the north-eastern part of South Asia, Bangladesh is administratively divided into 8 Divisions (Bibhag) and 64 Districts (Jela, Zila, Zela), 472 Upazillas (sub-districts), 496 thanas (police stations) and 4451 unions. Estimated population in Bangladesh is 16.47 million in 2020 (Worldometer, 2021). In June 2021, the estimated GDP per capita in Bangladesh reached 2097.000 USD (CEIC, 2021). According to the Asian Development Bank, the population living below the national poverty line was $21.8 \%$ in 2019 (ADB, 2021), increased by 8.2 percentage points to $30 \%$ during 2020-2021 than that of a non-Covid counterfactual scenario, as noted by the World Bank (The Financial Express, 2021). Life expectancy at birth in Bangladesh increased from 46.59 years in 1971 to 73.0 years in 2021 (Macrotrends, 2021).

In 2018, health expenditure per capita for Bangladesh was 42 US dollars (World Data Atlas, n.d.), which is 2.3 percent of the country's GDP, substantially lower than the South Asian and Lower Middle-Income Country (LMIC) average 
at 5.3 percent and 5.4 percent of GDP (Hosain and Ahmed, 2020). In comparison to other SAARC nations, people in Bangladesh pay a higher price on their treatment from their wallets (Fahim et al., 2018).

Addressing the issue of healthcare governance, the $4^{\text {th }}$ Health Sector Programme of the Government of Bangladesh (HPNSP, 2017-2022) is the first foundational programme towards universal health coverage and achieving targets towards the Sustainable Development Goals (DGHS, 2017). Key priorities of the HPNSP include: 1) a stronger governance and stewardship role of the MoHFW, building capacities in leadership, management, and regulation for better quality services; and 2) a more fit-for-purpose MoHFW, restructured to increase performance, efficiency and accountability while removing duplication and waste.

Health care delivery system in Bangladesh is based on the Primary Health Care (PHC) concept. PHC addresses the most of a person's health needs throughout their lifetime. This includes physical, mental, and social well-being and it is people-cantered rather than disease-cantered (World Health Organization, n.d.). The secondary level health care is provided through 500 bed capacities in district hospitals. The tertiary level health care is available at the medical college hospitals, public health and medical institutes and other specialist hospitals at the national level where a mass wide range of specialised as well as better laboratory facilities are available (Islam and Biswas, 2014).

\section{Healthcare System Organization}

The health sector of Bangladesh is a pluralistic system with four key actors that define the structure and function of the system: government, private sector, nongovernmental organizations (NGOs), known as the "third sector", and the donor agencies. The MoHFW, through the two Directorates General of Health Services (DGHS) and Family Planning (DGFP), manages a dual system of general health and family planning services through district hospitals, Upazila Health Complexes at subdistrict level, Union Health and Family Welfare Centers at union level, and community clinics at ward level. In addition, the Ministry of Local Government, Rural Development and Cooperatives manage the provision of urban primary care services. Besides, in recent time, research and training facilities have been considerably expanded in the country with medical schools, training centers and other public sector institutions under the control of the MoHFW. DGHS, the key sector agency at the implementation level, is responsible for regulating the public and private sectors aimed at improving quality standards in healthcare; safeguarding and improving the healthcare for the underserved groups; manage delivery of health care at various levels; and providing cross-cutting support services. Besides the Ministry, DGHS and the executing agencies discussed above, the organizational structure of healthcare service also includes the local government administration; sub-urban and community-based health complexes, clinics and family welfare centers; and associations of health 
professionals and consumers. As detailed below, the growth of the private sector in the recent time is significant in Bangladesh.

\subsection{Administration, Training and Research}

The MoHFW implements its programmes and provides services through different executing and regulatory authorities. The executing authorities include five Directorates of the Ministry and some other organizations, namely-Health Services, Family Planning, Drug Administration, Nursing Services, and the Health Engineering Department. The regulatory bodies of the health sector are the Bangladesh Medical and Dental Council (BMDC), Bangladesh Nursing Council (BNC), State Medical Faculty (SMF), the Ayurvedic, Homeopathy and Unani Board, and the Bangladesh Pharmacy Council (Ahmed et al., 2015).

To facilitate research and training in medical science, different public sector institutions under the control of the Ministry of Health and Family Welfare operate at the national level. There are 39 government medical colleges, six postgraduate institutes, three specialized institutes, two institutes of health technology and five medical assistant training schools in Bangladesh (All Result BD, 2021). For research there are five institutions: Bangladesh Institute of Child and Mother Health; Bangladesh Institute of Child Health; Bangladesh Medical Research Council; BIRDEM; National Institute of Cancer Research and Hospital. In addition, there are a few public health research and training institutions, including the Institute of Epidemiology, Disease Control and Research (IEDCR), Institute of Public Health (IPH), Institute of Public Health and Nutrition (IPHN) and National Institute of Preventive and Social Medicine (NIPSOM) (Azad, 2020).

\subsection{DGHS: Key Mandates}

\section{1) Leading improvement in public health}

This core mandate of the DGHS relates to the reduction of risk factors, promote healthy lifestyles, and address the environmental and societal determinants of health. It is to be noted that the key elements of a strong public health function include: a) health status monitoring; b) communicable disease surveillance; c) communicable disease control; d) non-communicable disease (NCD) reduction; e) improving the health of at-risk populations; f) fulfilling the country's international health obligations; g) research; and h) planning and managing the delivery of public health and primary health care (WHO, 2013).

\section{2) Improving health care quality through regulations and accreditation}

This mandate requires the DGHS to take a number of actions in order to ensure regulation over the public and private sectors so as to improve quality standards in healthcare by accreditation of individuals and organisations involved in the healthcare systems. The following three key stakeholders are particularly expected to be addressed by the Directorate's stewardship role and scope of application of the mandate: a) non-public providers b) publicly provided care; and c) 
professional regulatory bodies.

3) Safeguarding and improving the health of underserved and at-risk populations:

There is an expectation that DGHS will become a significant player in safeguarding and improving the health of the urban poor and other underserved groups such as hard to reach rural populations and tribal areas.

4) Managing the delivery of health care at primary, secondary and tertiary levels

A core mandate of the Directorate is to provide clinical care at tertiary and secondary levels, ensuring access to patients for the clinical education of medical and other students, managing district hospitals and clinical services at UHCs together with managing the delivery of primary health care at the sub-centres and community clinics.

5) Providing support services

Cross-cutting support services are needed that relate to each of the core mandates outlined above to ensure that the DGHS is able to fulfil its role and responsibilities. These particularly include: a) health system planning; b) budgeting and accounting; c) workforce development; d) developing management skills (especially in the post-COVID scenario); e) procurement and distribution of supplies, medicines and equipment; f) management information system; g) developing IT infrastructure; h) establishing a competent legal affairs department; i) ensure timely, authoritative and professional public relations-both proactively and reactively.

\subsection{Other Public Sector Health Services}

Besides the MoHFW, MoLGRDC, the DGHS and its five executing agencies (Directorate Generals) and the public medical colleges, hospitals and institutions stated above, the following other agencies form part of the key health service delivery organizational structure in Bangladesh (Ahmed et al., 2015): City Corporations; local NGOs or private providers; Maternal and Child Welfare Centres (MCWC); Union Health and Family Welfare Centres (UHF \& WC); district and general/specialized hospitals; Upazilla (sub-district) Health Complex (UHC); Union (lowest tier of local government) Sub-Centres (USC); Rural Sub-Centres (RSC); and Community Clinics (CC).

\subsection{Private Sector Providers}

In the private sector, providers in Bangladesh can be grouped into two main categories. First, the organized private sector (both for-profit and non-profit) which includes qualified practitioners of different systems of medicine. Apart from modern medicine, traditional medicine is widely practiced in the private sector. Second, the private informal sector, which consists of providers not having any formal qualifications such as untrained allopaths, homeopaths, kobiraj (people traditionally practising Ayurveda), etc., known as alternative private 
providers. These informal or traditional private service providers mostly serve the poor in rural areas (ICDDRB, 2018).

The formal, for-profit or non-profit service institutions are mostly located in urban areas. Private facilities including medical colleges, hospitals, clinics, laboratories, and drug stores are being established in increasing numbers in the capital city as well as other divisional headquarters. This causes geographic inequity in health service provision. The private facilities are often staffed with public sector health personnel.

The growth of the private sector compared to the public sector is significant in Bangladesh. Along with the increasing number of hospitals and hospital beds, over the last few years the private sector has witnessed a tremendous growth of teaching institutions. For instance, in 1996 there were no medical colleges or any teaching institutions in the private sector, but by 2011 the private sector had 44 medical colleges (Ahmed, Alam and Anwar et al., 2015) increased to 83 in 2021 (All Result BD, 2021).

Along with private clinics and hospitals, the number of diagnostic centres in the private sector is growing. According to a recent national survey carried out just before the COVID-19 pandemic by the Bangladesh Bureau of Statistics (BBS, 2019), over the past 20 years, Bangladesh has seen a number of its registered private hospitals go through a four-fold increase from 1125 to 4452; clinics have grown three-fold from 411 to 1397; dental clinics nearly seven-fold from 122 to 839; and diagnostic centres six-fold from 1778 to 10,291 . Of the total 16,979 private sector healthcare institutions, Bangladesh is now home to private diagnostic centres that account for $60.61 \%$ (Ahmed, 2021).

The NGO sector has emerged as the "third sector", providing new options and innovations. Bangladesh is known worldwide for having one of the most dynamic NGO sectors, with over 4000 NGOs working in the population, health, and nutrition sector. These NGOs are well-equipped with training and research facilities and information management systems. Besides, international donor partners of the country, both multilateral and bilateral, are also actively engaged in health-care financing and planning.

Finally, in Bangladesh, there are various professional organisations who address the rights of medical professionals at different levels, such as the Bangladesh Medical Association (BMA), Bangladesh Private Medical Practitioners Association (BPMPA), Public Health Association of Bangladesh, Bangladesh Paediatric Society, and the Nephrology Society of Bangladesh (Mujeri and Mujeri, 2020). However, there is no organised body, either in the public or private sector, for overseeing the interests of the patients. The Consumers Association of Bangladesh is an NGO addressing the rights of health sector clients.

\section{Sector Specific General Challenges of Healthcare Governance in Bangladesh}

Despite its multifaceted successes, the Bangladesh health system continues to 
suffer from many drawbacks and challenges. To summarise, the major areas of challenges include: an excessively centralized health service administration, a poor governance mechanism and regulatory framework, fragmented public service delivery, fragile management and administrative capability in the MoHFW, inefficient allocation of public resources, lack of regulation of the private sector, shortage of HRH, high turnover and absenteeism of health workers, and poor maintenance of health facilities and medical equipment (WHO, 2021). Besides, some other major drawbacks of the health system governance include: limited public facilities; compromised access; lack of essential commodities; lack of devolution; lack of local level planning; misuse or misappropriation of resources; lack of community empowerment at the local level; lack of public health and management expertise at the district and Upazila levels; growing and continuing inequity within the health system; political instability and lack of commitment; and weak health information system (Osman, 2008).

For funding and developing relevant strategies and service delivery frameworks, the healthcare system of Bangladesh largely depends on the government or the public sector. Even though the health sector faces numerous intractable problems, in terms of national resource distribution, it appears to have no focus. With just $2.3 \%$ of the GDP allocated for health care, Government health spending is just around $36 \%$ of total health expenditure, the remainder $(73.9 \%)$ are out-of-pocket (OOP) expenditure (World Data Atlas, 2018). Therefore, along with inequity, inequality is also a major concern for the healthcare sector.

Much of the successes of Bangladesh in the health sector over the past years, albeit most of which are in infrastructure development, have been adversely affected by deep-rooted corruption and misappropriation of public funds-often with political patronisation (Iftekharuzzaman, 2021). As per the National Household Survey of Transparency International Bangladesh (TIB, 2012), 40.2\% of public institution health care beneficiaries were sufferers of misconduct and corruption at the service delivery points. The TIB study shows that nationally the overall figure of bribery in this field was Tk. 703 million. News articles are frequently released in the media on issues like absences of physicians, lack of consistency of care, deficiencies in spaces and active involvement of out-side intermediaries (often referred to as dalal or broker) drawing patients to private hospitals, lack of professionalism, financial corruption by health practitioners, hospital personnel and the administration as a whole.

The picture depicted above has been particularly blown-up following the outbreak of the corona virus in the country. The first COVID patient was detected in Bangladesh in March 2020. In fact, the government was not much focused on this deadly pandemic and the overall response or planning was very weak and ineffective. In fact, it would not be an exaggeration to say that the everyday news during the initial months of the pandemic in Bangladesh were overshadowed by news and public attention on increasingly exposed incidences of corrupt practices both in the public and private sectors, exploitation and misappropriation of 
public funds, poor administration and mismanagement (Hossain, Shakila and Parvin, 2020).

Many Bangladeshi health sector actors were arrested for allegedly selling sham COVID-19 negative certificates. The most controversial incident of which arose when law enforcement agencies carried out a raid on a local private hospital in the capital, which was one of the very few private hospitals permitted by the government for conducting treatment of COVID-19 patients (Sumon, 2020).

Another crucial challenge facing the healthcare industry in Bangladesh is the shortage of health workforce, inappropriate skill-mix and inequitable distribution of human resources (Ahmed et al., 2011). As per the MoHFW's HRD Datasheet, 2011, there were 3.05 physicians per 10,000 population and 1.07 nurses per 10,000 population in the country (WHO, 2021). The ratio of nurses to doctors in Bangladesh is among the lowest in the globe (1:3) while as per WHO, this should be the opposite. Also, many physicians and other healthcare personnel are not found at their posting sites, which has become a normal practice almost everywhere in Bangladesh.

It is, however, noteworthy that even being a resource deprived country, Bangladesh has made remarkable health improvements, which is an inspiration for all other developing nations. Health related benchmarks such as life expectancy and immunisation levels have increased substantially over the past decades, while infant mortality, maternal deaths and fertility rates have fallen dramatically. However, most of these successes are largely quantitative, whereas qualitative enhancement is minimal. Poor accessibility, insufficient level of care, increasing maternal mortality rates and weak child state of health represent the problems facing the health sector (Osman, 2008).

Expenditures linked to healthcare in Bangladesh are rising every day. Each year, many people plunge into debt to pay health bills, and many more are nearing death while struggling to afford the necessary funds for their care. As per a World Bank study (World Bank Group, 2018), some 64 lakhs people in Bangladesh are hitting poverty only to fulfil their medical costs each year.

\section{Health Sector Regulatory Framework}

\subsection{International Legal Framework}

As defined by the World Health Organisation (WHO) Constitution, right to health entails "enjoyment of the highest attainable standard of health as a fundamental right of every human being" (WHO, 2017a). Furthermore, health is defined as a state of complete physical, mental, and social well-being and not merely the absence of disease or infirmity (WHO, n.d.). Likewise, the Universal Declaration of Human Rights (UDHR) has addressed the underlying economic and social factors (e.g. Food, clothing, safe housing, sanitation, gender equality, social welfare services etc.) affecting health, thus setting a high threshold which signatory states are obliged to uphold through effective allocation and maximum utilization of available resources ( $\mathrm{OHCHR}$, n.d.). Additionally, the Committee 
on Economic, Social and Cultural Rights in General Comment No. 14 (OHCHR, 2000) has conceptualized the core principles crucial to the right to health (Article 12); they are: 1) Availability, 2) Accessibility, 3) Acceptability (i.e. people cantered approach); 4) and Quality of services and facilities (WHO, 2017b).

Besides the above stated international standards, numerous other instruments contain provisions regarding right to healthcare (see, for instance, Hunt, 2016). Instances of some these specifically include-Convention on the Rights of Persons with Disabilities, CRPD (2006); Constitution of the World Health Organization (1946); Declaration of Alma Ata on Primary Health Care (1978); Declaration of Commitment on HIV/AIDS (2001); Declaration of Astana on Primary Health Care (2018); and the Beijing Platform for Action-Women and health (1995).

\subsection{Health Sector Policies, Laws and Regulations in Bangladesh}

\section{1) Principal Policy: Bangladesh National Health Policy 2011 (NHP)}

The Constitution of Bangladesh places top priority on public health and nutrition as a state policy of governance. Article 15(a) of the Constitution states: [I]t shall be a fundamental responsibility of the State to attain, through planned economic growth, ... with a view to securing to its citizens-(a) the provision of the basic necessities of life, including food, clothing, shelter, education and medical care. Article 18 (1) further declares that "the State shall regard the raising of the level of nutrition and the improvement of public health as among its primary duties". At the international level, the recognition of health as a fundamental right by WHO and subsequent approval of health as an instrument of welfare by the UDHR and the ICSECR further enhances Bangladesh's commitment to health and nutrition. As noted earlier, Bangladesh also expressed agreement on the Alma Ata Declaration (1978); the World Summit for Children (1990); International Conference on Population and Development (1994); Beijing Women's Conference (1995); MDGs (especially MDG 4: "Reduce child mortality" and MDG 5: "Improve maternal health") and the SDGs (esp. Goal 3: "Ensure healthy lives and promote well-being for all at all ages") (Amin, 2019).

To implement the obligation of the Constitution, and the global commitment and expectation of the people at large, successive governments in Bangladesh had taken initiatives in the past to prepare a pragmatic health policy for the nation. In 1998, the Ministry of Health and Family Welfare formulated Health and Population Sector Strategy (HPSS) and also formulated a Health and Population Sector Programme (HPSP) (Jahan, 2007). However, the problems in the health services multiplied in the absence of a written and approved national health policy while the national Annual Development Programs and the Five-Year Plans continued to substitute for policy principles in the health sector (Murshid and Haque, 2020). To address the vacuum, the Bangladesh National Health Policy document was published in 2011 by the Ministry of Health and Family Welfare. The 2011 Policy contains 19 goals and objectives, 16 policy principles and 39 
strategies adhering to the following basic norms and standards:

a) Every citizen has the basic right to adequate health care. The State and the government are constitutionally obliged to ensure health care for its citizens.

b) To ensure an effective health care system that responds to the need of a healthy nation, health policy provides the vision and mission for development.

c) Pursuit of such policy will fulfil the demands of the people of the country, while health service providers will be encouraged and inspired. People's physical well-being and free thought process have proved to be a precondition for the growth and intellectual enrichment in today's human society.

2) Key National Laws and Regulations:

The following policies, laws and regulations constitute the regulatory framework for the health sector governance in Bangladesh (see, Biswas, Pervin and Tanim et al., 2017; also, Karim and Alam, 2020):

- Price Guide for Medical Equipment-HSD

- Standardization of Medical Equipment (USAID)

- Condemnation Guidelines for Use in Hospitals and Health Institutions (DGHS/ USAID)

- Policy for Distribution/Allocation of Hearing Aids Collected with Government Funding

- Mental Health Act, 2018

- Transplantation of Human Organs (Amendment) Act, 2018

- Sheikh Hasina Medical University Act, 2019 (Draft)

- Recruitment Rules for Non-Medical Staff of the Health Department, 2018

- Policy Regarding the Arrival of Foreign Specialist Doctors/Specialized Nurses, 2018

- Pilgrim Healthcare Policy, 2018

- Medical Education-1: Chittagong Medical Law, 2016.

- Medical Education-1: Rajshahi Medical Law, 2016.

- Bangladesh Medical \& Dental Council Act, 2010

- Bangabandhu Sheikh Mujib Medical University Act, 1998

- The Public Health (Emergency Provisions) Ordinance, 1944

- The Malaria Eradication Board Ordinance, 1961

- The Bangladesh Malaria Eradication Board (Repeal) Ordinance, 1977

- The Prevention of Malaria (Special Provisions) Ordinance, 1978

- The Epidemic Diseases Act, 1897

- The Vaccination Act, 1880

- The Essential Services (Second) Ordinance, 1958

- The Medical and Dental Council Act, 1980

- The Medical Council (Amendment) Act, 1963

- The Bangladesh Nursing Council Ordinance, 1983

- The Pharmacy Ordinance, 1976

- The Drugs Act, 1940

- The Drugs (Amendment) Act, 1963 
- The Drugs (Control) Ordinance, 1982

- The Drugs (Supplementary Provisions) Ordinance, 1986

- The Drugs (Control) (Amendment) Act, Ordinance, 2006

- The International Centre for Diarrhoeal Disease Research Ordinance, 1978

- International Centre for Diarrhoeal Disease Research, Bangladesh (Amendment) Act, 1978

- The Medical Service of Pakistan Order (Repeal) Act, 1963

- The Medical Practice Private Clinics and Laboratories (Regulation) Ordinance, 1982

- The Medical Practice Private Clinics and Laboratories (Regulation) (Amendment) Ordinance, 1984

- The Medical Council Act, 1973

- The Medical Council (Amendment) Ordinance, 1976

- The Medical Diplomas Act, 1939

- The Medical Colleges (Government Bodies) Ordinance, 1961

- The Medical Diplomas (Repeal) Act, 1966

- The Medical Degrees Act, 1916

- The Allopathic System (Prevention of Misuse) Ordinance

- The Bangladesh Homeopathic Practitioner Ordinance, 1983

- The Bangladesh College of Physicians and Surgeon Order, 1972

- The Bangladesh Unani and Ayurvedic Practitioner Ordinance, 1983

- The Unani, Ayurvedic and Homeopathic Practitioner (Amendment) Ordinance, 1966

- Human Organ Transplantation Act, 1999

- Smoking and Tobacco Use (Control) Act, 2005

- Safe Blood Transfusion Act, 2002

- Iodine Deficiency Disease Prevention Act, 1989

- The Breast-Milk Substitutes (Regulation of Marketing) Ordinance, 1984

- Alternative Food to Breastfeeding (Marketing Control) Rules, 1993

- Institute of Child and Maternal Health Act, 2002

\section{Specific Regulatory Issues \& Challenges}

\subsection{General Observations}

Apart from its organisational and structural issues, discussed above, appropriate policies and regulatory frameworks also reflect establishment of good governance in health administration, both in the private and the public sectors. Existing laws relating to private clinics, diagnostic centres and private practices need to be reviewed in order to draw a comprehensive regulatory and standard setting framework for licensing, service provisions, accountability and management (see, e.g. Barkat, Karim, Shah and Ali, 2001). All government allocations should be demand based and balanced, especially between urban and rural healthcare systems (Naher et al., 2020). Provisions should be made in a revised policy framework to facilitate interaction of civil society organisations, health watch 
groups and other private sectors to ensure accountability and transparency in procurement, supply chain management and logistics as well as establishing a well-functioning information system (USAID and SIAPS, 2017).

Existing human resource plans, rules and regulations need to be reconstructed to have long-term objective to improve the quality of healthcare services (both clinical and managerial). Relevant regulatory frameworks should also address the need for tailor-made programmes to be provided in line with local needs to deliver services to hard-to-reach, at-risk and vulnerable populations (Shahen, Islam and Ahmed, 2020).

It is important that the Directorate has access to competent legal advice and expert services on such issues as adherence to legislation and development of new proposals as required, land (and other assets) ownership, acquisition and management, workforce law, and international laws. While maintaining a panel of competent retainers is imperative, DGHS need to focus on enhancing the capacity and skills of its own in-house legal and regulatory resources.

\subsection{Specific Challenges and Recommendations}

Existing policy and regulatory frameworks of the country pertaining to the health sector, including in particular the Health Policy 2011, need to be reviewed. Such reviews should ideally include, but not limited to, the following:

1) Reemphasized strategy of devolution, going beyond mere decentralization and delegation, in and within DGHS and the MoHFW is of paramount importance. Although generally decentralized, the health system in Bangladesh never went through a process of effective devolution. Executive power and effective decision-making remained concentrated in the MoHFW in the capital city Dhaka with the UHCs simply carrying out plans and programs decided by the Ministry. Plans and programs, therefore, often do not reflect local realities. The Government thus needs to review and undertake necessary regulatory initiatives and directives to materialize the process of devolution.

2) Increased emphasis on inter and intra-departmental/ministerial coordination ensuring balance of resources and efforts (urban-rural, public-private, GONGOs, etc.), avoiding conflicts as well as double-dipping and overlaps.

3) A comprehensive regulatory and policy framework for the private sector health services including revision of the 1982 law (The Medical Practice Private Clinics and Laboratories (Regulation) (Amendment) Ordinance, 1984) (amended in 1984) clearly laying out a set of codes, standards and a service-focused, user-friendly clinical-managerial regulations (from licensing to monitoring) for private clinics/hospitals, pharmaceuticals, pharmacies, diagnostic/pathological centres/private practices (doctors, nursing and other clinical/non-clinical technical staff), traditional and indigenous health care services and service providers, etc.

4) Develop a revised set of Human Resource Manual, Service Rules and Codes of Conduct for the DGHS (broadly) ensuring consistency (grades, titles, career 
progression), balance in distribution of responsibilities and line of supervision, new recruitment criteria for specialized line managers for technical/special departments (e.g. IT career personnel for ICT in the managerial positions, media for media \& PR, legal experts for law and policy, etc.).

5) Creation of an Urban Health Unit within the DGHS is essential.

6) With a view to reconcile and align the legal and regulatory frameworks and rules of service, codes of conduct and professional/ethical standards applicable to the regulatory bodies of medical education and services (public and private), a thorough review may be undertaken on existing policy norms and principles.

\section{HRB Approaches to Health Governance}

In the 21st century, access to healthcare is no longer considered a privilege but a fundamental right and the duty is upon the governments to ensure that no human being is deprived of this basic right (Tang, Eisenberg and Meyer, 2004). Furthermore, given the ground-breaking advancements made in health-related human rights, the shared goal is now to ensure proper implementation of these rights through effective governance across nations.

Let's first take a quick look at what is signified by HRB approach in the context of healthcare services and management. As noted: "[A] human rights approach to health is critical to address growing global health inequalities" (London, 2008). The approach enables people to know and claim their rights, promotes accountability of responsible individuals and institutions, and ensures freedom from discrimination in healthcare services on any ground whatsoever. In other words, the HRB approach is founded on five key fundamental precincts of participation, accountability, non-discrimination and equality, empowerment and legality (ibid.). The HRB approach has been seen to possess two key objectives: 1) to empower rights-holders to claim and exercise their rights; and 2) to strengthen capacity of duty-bearers who have the obligation to respect, protect, promote, and fulfil human rights (ENNHRI, n.d.).

Thus, to summarise, a human rights-based approach signifies that the fundamental human rights norms and standards are integrated in the design, implementation and M\&E of health-related policies and programs. These particularly include promoting human dignity, emphasizing on the needs and rights of vulnerable groups, and ensuring that the health systems are made accessible to all without discrimination (see, Gloppen, Langford and Yamin et al., 2016; also, Marks, 2014: p. 219). A particular emphasis of HRB approaches is to prioritise service provisions for people in the most marginalised or vulnerable situations facing difficult barriers to realising their rights.

Again, realization of the importance of human rights in healthcare has led to increased demands for greater transparency and accountability in public health to ensure protection of these rights. Scholars, practitioners and advocates have devised accountability mechanisms through which commitment of state and state bodies towards protecting human rights in public health can be monitored 
and ensured (Obregon and Waisbord (Eds), 2012: p. 190). These mechanisms include, among others, political advocacy and social movements on the recognition, promotion and protection of health-related human rights as well as raising awareness and community mobilisation to influence policy making in public health (Meier, Evans and Kavanagh et al. 2018). As note by Harrington and Stuttaford (2010: p. 62), an aggrieved party whose right to health has been violated can seek remedy in the courts of law. In addition, all UN member States' commitment towards protection of health-related human rights are monitored by the UN Human Rights Council through review of periodic reports, mutual engagement in "constructive dialogue" and issuing concluding observations (Bueren, 2010: p. 185).

However, despite global commitments and developments in this regard, failure to ensure access to healthcare for underprivileged and marginalized groups remains a major challenge. In many parts of the world access to healthcare still stands a distant dream for millions of people. Factors such as gender, financial status, migrant status, race, population, safe housing, sanitation etc. also contribute towards the deprivation of health and other human rights of disadvantaged groups (Connell, 2010: p. 12). Besides, reports suggest that discriminatory laws and policies further aggravate suffering of underprivileged marginalized groups and hinder their right to access to healthcare (UNAIDS, 2016).

The on-going COVID-19 pandemic has severely disrupted the healthcare systems across nations, including Bangladesh. With the spread of the virus and the casualties that followed, many countries' healthcare systems are struggling to cope with the immense pressure owing to rapid and unprecedented changes, significant gaps in the health system (Human Rights Watch, 2020), and poor adherence to international health right standards. Moreover, lack of access to and unavailability of healthcare, shortage of medical services such as diagnostic tests, ventilators, and oxygen; lack of PPE and training for health and frontline workers, etc. has led to marginalization and violation of people's health rights (Pūras, Mesquita and Cabal et al., 2020). It may be noted in this context that as per the International Covenant on Economic, Social and Cultural Rights, 1966, Article 12, it is obligatory on governments to take necessary steps for the "prevention, treatment and control of epidemic, endemic, occupational and other diseases", and "assure to all, medical service and medical attention in the event of sickness".

\section{Conclusion}

In order to implement and sustain the recommended reforms discussed above, a comprehensive, revised health policy is essential for ensuring a transparent, accountable, equitable and predictable governance within the overall healthcare mechanism of the country. The brief analysis of the health sector institutional and regulatory frameworks in Bangladesh clearly depicts that along with lack of adequate public health facilities, scarcity of skilled workforce and inadequate fi- 
nancial resources, absence of a dynamic and proactive stewardship remains among the most crucial challenges in reforming the existing healthcare system.

As emerged from the foregoing discussion, from the legal and institutional capacity perspectives, the core vision is embedded in the fact that the DGHS (along with the MoHFW) need to undertake multi-sector and cross-actor participatory initiatives in order to design, enforce and sustain policies, regulations and strategies to further strengthen and enhance performance of the Directorate, and more broadly, the overall health system.

The Government of Bangladesh has initiated a plan to make the country a middle-income nation within 2021. For meeting the goal, above $10 \%$ of the overall budget must be allocated for healthcare. A multi-sector systemic approach would thus be one of the essential approaches to address the problems of the healthcare industry in the country (Saha, 2019).

What has been ignored in the past, involving the local authorities and grassroots providers in the policy formulation and decision-making, need to be reconsidered. A strong leadership is of great essence in this process. Such leadership could bring about meaningful and effective health system reform, which will work more efficiently for the betterment of the health of the people of the country built upon the values of equity, efficiency, and accountability.

\section{Conflicts of Interest}

The author declares no conflicts of interest regarding the publication of this paper.

\section{References}

ADB (2021). Bangladesh and ADB. Poverty Data: Bangladesh. https://www.adb.org/countries/bangladesh/poverty

Ahmed, R. (2021, July 5). Private Healthcare Facilities Growing in Number but Lack Emergency Services. Dhaka Tribune.

https://www.dhakatribune.com/health/2021/07/05/private-health-facilities-growing-innumber-but-lack-emergency-services

Ahmed, S. M., Alam, B. B., Anwar, I., Begum, T., Huque, R., Khan, J. A. M. et al. (2015). Bangladesh Health System Review: Health Systems in Transition (Vol. 5). Asia Pacific Observatory on Public Health Systems and Policies, World Health Organization. https://iris.wpro.who.int/bitstream/handle/10665.1/11357/9789290617051_eng.pdf

Ahmed, S. M., Hossain, M. A., Chowdhury, A. M. R., \& Bhuiya, A. U. (2011). The Health Workforce Crisis in Bangladesh: Shortage, Inappropriate Skill-Mix and Inequitable Distribution. Human Resources for Health, 9, Article No. 3.

https://doi.org/10.1186/1478-4491-9-3

https://human-resources-health.biomedcentral.com/articles/10.1186/1478-4491-9-3

All Result BD (2021, February 3). List of Govt Medical Colleges in Bangladesh 2021. https://allresultbd.com/govt-medical-college-list/

Amin, Z. A. (2019, September 20). Health System in Bangladesh. Slideshare. https://www.slideshare.net/zulfiquer732/health-system-of-bangladesh-174118589

Azad, A. K. (2020). National Preparedness and Response Plan for COVID-19, Bangla- 
desh. Health Service Division, Ministry of Health and Family Welfare, Government of the People's Republic of Bangladesh.

https://reliefweb.int/sites/reliefweb.int/files/resources/nprp_covid-19_v6_18032020.pdf

Barkat, A., Karim, M. A., Shah, M. M. R., \& Ali, M. I. (2001). Health Legislation in Bangladesh: A Content Analysis and Scopes for Improvement. Human Development Research Centre.

https://www.hdrc-bd.com/wp-content/uploads/2018/12/03.-Health-Legislation-in-Ban gladesh.pdf

BBS (Bangladesh Bureau of Statistics) (2019). Report on the Survey of Private Healthcare Institutions.

http://bbs.portal.gov.bd/sites/default/files/files/bbs.portal.gov.bd/page/b343a8b4_956b_ 45ca_872f_4cf9b2f1a6e0/2021-06-30-04-58-22ea330d54a12a1b26bb608d43130b91.pdf

Biswas, T., Pervin, S., Tanim, M. I. A., Niessen, L., \& Islam, A. (2017). Bangladesh Policy on Prevention and Control of Non-Communicable Diseases: A Policy Analysis. Journal of Translational Medicine, 17, Article No, 582.

https://doi.org/10.1186/s12889-017-4494-2

https://bmcpublichealth.biomedcentral.com/articles/10.1186/s12889-017-4494-2

Bueren, G. V. (Ed.) (2010). Freedom from Poverty as a Human Right: Law's Duty to the Poor (p. 185). United Nations Educational, Scientific and Cultural Organization.

CEIC (2021). Bangladesh GDP Per Capita. Global Economic Data, Indicators, Charts \& Forecasts. https://www.ceicdata.com/en/indicator/bangladesh/gdp-per-capita

Connell, J. (2010). Migration and the Globalisation of Health Care: The Health Worker Exodus? Edward Elgar Publishing. https://doi.org/10.4337/9781849805186

DGHS (Directorate General of Health Services) (2017). 4th Health, Population and Nutrition Sector Programmme (4th HPNSP). Health Service Division, Ministry of Health and Family Welfare, Government of the People's Republic of Bangladesh, 2017. http://hospitaldghs.gov.bd/wp-content/uploads/2020/01/HSM_OP_2017-22.pdf

ENNHRI (European Network of National Human Rights Institutions) (n.d.). Human Rights Based Approaches. European Network of National Human Rights Institutions. https://ennhri.org/about-nhris/human-rights-based-approach/

Fahim, S. M., Bhuayan, T. A., Hassan, M. Z., Zafr, A. H. A., Begum, F., Rahman, M. M. et al. (2018). Financing Health Care in Bangladesh: Policy Responses and Challenges towards Achieving Universal Health Coverage. The International Journal of Health Planning and Management, 34, e11-e20.

https://onlinelibrary.wiley.com/doi/abs/10.1002/hpm.2666

Gloppen, S., Langford, M., Yamin, A., Iunes, R., Cubillio, L., Escobar, M.-L. et al. (2016). Operationalizing a Rights-Based Approach to Health Service Delivery. Chr. Michelsen Institute/NORAD.

https://www.cmi.no/projects/1791-operationalizing-a-rights-based-approach-to-health

Govindaraj, R., Raju, D., Secci, F., Chowdhury, S., \& Frere, J.-J. (2018). Findings on Urban Health Sector Governance in Bangladesh. In Health and Nutrition in Urban Bangladesh: Social Determinants and Health Sector Governance (pp. 61-83). World Bank Group E-Library. World Bank. https://doi.org/10.1596/978-1-4648-1199-9_ch4 https://elibrary.worldbank.org/doi/10.1596/978-1-4648-1199-9_ch4

Harrington, J., \& Stuttaford, M. (2010). Global Health and Human Rights: Legal and Philosophical Perspectives. Routledge. https://doi.org/10.4324/9780203850633

Hosain, M. R., \& Ahmed, S. A. (2020, July 26). Case for Building a Stronger Health Care System in Bangladesh. The World Bank.

https://blogs.worldbank.org/endpovertyinsouthasia/case-building-stronger-health-care 
-system-bangladesh

Hossain, M. A., Shakila, M., \& Parvin, M. (2020). Governance of Covid-19 Pandemic in Bangladesh: Crisis and Challenges. Journal of Public Health Policy and Planning, 4, 85-89.

http://www.alliedacademies.org/articles/governance-of-covid19-pandemic-in-banglade sh-crisis-and-challenges-15048.html

Human Rights Watch (2020). Human Rights Dimensions of COVID-19 Response. https://www.hrw.org/news/2020/03/19/human-rights-dimensions-covid-19-response\# Toc35446577and

Hunt, P. (2016, December 3). Interpreting the International Right to Health in a Human Rights-Based Approach to Health. Health and Human Rights Journal.

http://www.hhrjournal.org/2016/12/interpreting-the-international-right-to-health-in-a -human-rights-based-approach-to-health/

ICDDRB (International Centre for Diarrhoeal Disease Research, Bangladesh) (2018, June 11). Engaging Private Sector to Achieve Universal Health Coverage.

http://blog.icddrb.org/2018/06/11/engaging-private-sector-to-achieve-universal-health -coverage/

Iftekharuzzaman (2021, January 12). Political Contents of Corruption and Anti-Corruption in Bangladesh. The Daily Star.

https://www.thedailystar.net/opinion/news/political-contents-corruption-and-anti-corr uption-bangladesh-1960161

Islam, A., \& Biswas, T. (2014). Health System in Bangladesh: Challenges and Opportunities. American Journal of Health Research, 2, 366-374.

https://doi.org/10.11648/j.ajhr.20140206.18

https://www.researchgate.net/publication/276105127_Health_System_in_Bangladesh_ Challenges_and_Opportunities

Jahan, R. (2007). Securing Maternal Health through Comprehensive Reproductive Health Services: Lessons from Bangladesh. American Journal of Public Health, 97, 1186-1190. https://doi.org/10.2105/AJPH.2005.081737 http://www.ncbi.nlm.nih.gov/pmc/articles/PMC1913082/

Karim, S. M. T., \& Alam, S. (2020). The Health Care System in Bangladesh: An Insight into Health Policy, Law and Governance. Australian Journal of Asian Law, 20, Article No. 6. https://papers.ssrn.com/sol3/papers.cfm?abstract_id=3553045

London, L. (2008, June). What Is a Human-Rights Based Approach to Health and Does It Matter? Health and Human Rights Journal, 10, 65-80.

https://doi.org/10.2307/20460088

https://www.hhrjournal.org/2013/09/what-is-a-human-rights-based-approach-to-healt h-and-does-it-matter

Macrotrends (2021). Bangladesh Life Expectancy 1950-2021. https://www.macrotrends.net/countries/BGD/bangladesh/life-expectancy

Marks, L. (2014). Governance, Commissioning and Public Health (p. 219). Policy Press. https://doi.org/10.1332/policypress/9781447304944.003.0008

Meier, B. M., Evans, D. P., Kavanagh, M. M., Keralis, J. M., \& Armas-Cardona, G. (2018). Human Rights in Public Health: Deepening Engagement at a Critical Time. Health Hum Rights, 20, 85-91. https://www.ncbi.nlm.nih.gov/pmc/articles/PMC6293343/

Molla, M. A. M. (2021, November 5). People Fork Out Most: Govt Report Shows Healthcare Costliest in South ASIA. The Daily Star.

Mujeri, M. K., \& Mujeri, N. (2020). Bangladesh at Fifty: Moving beyond Development Traps (p. 55). Springer. https://doi.org/10.1007/978-3-030-56791-0 
Murshid, M., \& Haque, M. (2020). Hits and Misses of Bangladesh National Health Policy 2011. Journal of Pharmacy and Bioallied Sciences, 12, 83-93. https://www.ncbi.nlm.nih.gov/pmc/articles/PMC7373115/

Naher, N., Hoque, R., Hassan, M.S., Balabanova, D., Adams, A. M., \& Ahmed, S. M. (2020). The Influence of Corruption and Governance in the Delivery of Frontline Health Care Services in the Public Sector: A Scoping Review of Current and Future Prospects in Low and Middle-Income Countries of South and South-East Asia. BMC Public Health, 20, Article No. 880. https://doi.org/10.1186/s12889-020-09197-0 https://bmcpublichealth.biomedcentral.com/articles/10.1186/s12889-020-08975-0

Obregon, R., \& Waisbord, S. (Eds.) (2012). The Handbook of Global Health Communication (p. 190). John Wiley \& Sons. https://doi.org/10.1002/9781118241868

OHCHR (Office of the High Commissioner for Human Rights) (2000). CESCR General Comment No. 14: The Right to the Highest Attainable Standard of Health (Article No. 12). Adopted at the Twenty-Second Session of the Committee on Economic, Social and Cultural Rights, on 11 August 2000 (Contained in Document E/C.12/2000/4). http://www.refworld.org/pdfid/4538838d0.pdf

OHCHR (Office of the High Commissioner for Human Rights) (n.d.). International Standards on the Right to Food. United Nations Human Rights Office of the High Commissioner. http://www.ohchr.org/EN/Issues/Food/Pages/Standards.aspx

Osman, F. A. (2008). Health Policy, Programmes and System in Bangladesh. South Asian Survey, 15, 263-288. https://doi.org/10.1177/097152310801500206

https://www.researchgate.net/publication/249767833_Health_Policy_Programmes_and System_in_Bangladesh https://journals.sagepub.com/doi/abs/10.1177/097152310801500206?journalCode=sasa

Pūras, D., Mesquita, J. B., Cabal, L., Maleche, A., \& Meier, B. M. (2020). The Right to Health Must Guide Responses to COVID-19. The Lancet, 395, 1888-190. https://doi.org/10.1016/S0140-6736(20)31255-1 https://www.thelancet.com/journals/lancet/article/PIIS0140-6736(20)31255-1/fulltext

Saha, S. K. (2019, April 7). Facing Health Sector Challenges. NewAge. https://www.newagebd.net/article/69354/facing-health-sector-challenges

Shahen, M. A., Islam, M. R., \& Ahmed, R. (2020). Challenges for Health Care Services in Bangladesh: An Overview. IOSR Journal of Nursing and Health Science, 9, 13-24. https://www.iosrjournals.org/iosr-jnhs/papers/vol9-issue1/Series-1/C0901011324.pdf

Sumon, S. (2020, July 11). Health Workers in Bangladesh Charged with Selling Fake COVID-19 Certificates. Arab News. https://www.arabnews.com/node/1702946/world

Tang, N., Eisenberg, J. M., \& Meyer, G. S. (2004). The Roles of Government in Improving Health Care Quality and Safety. The Joint Commission Journal on Quality and Safety, 30, 47-55. https://doi.org/10.1016/S1549-3741(04)30006-7

The Financial Express (2021, April 13). Bangladesh's Poverty Rate Rises to 30pc Amid Pandemic. Financial Express Report. https://thefinancialexpress.com.bd/economy/bangladeshs-poverty-rate-rises-to-30pc-a mid-pandemic-1618291091

TIB (Transparency International Bangladesh) (2012). Health Sector: Governance Challenges and the Way Forward. Executive Summary.

https://www.ti-bangladesh.org/beta3/index.php/en/research-policy/92-diagnostic-study/4 440-health-sector-governance-challenges-and-the-way-forward-ex-summary-english

UNAIDS (Joint United Nations Programme on HIV/AIDS) (2016). Eliminating Discrimination in Health Care.

www.unaids.org/sites/default/files/media_asset/eliminating-discrimination-in-health-c are_en.pdf 
USAID (United States Agency for International Development) \& SIAPS (Systems for Improved Access to Pharmaceuticals and Services) (2017). Strengthening Governance in Procurement in Bangladesh. Systems for Improved Access to Pharmaceuticals and Services and the USAID, SIAPS Technical Brief.

http://siapsprogram.org/wp-content/uploads/2017/10/Strengthening-Governance-in-P rocurement-in-Bangladesh.pdf

WHO (World Health Organization) (2013). National Communication Strategy and Action Plan for Reduction of NCD High Risk Behaviours in Bangladesh, 2014-2016. Bureau of Health Education.

https://cdn.who.int/media/docs/default-source/searo/bangladesh/pdf-reports/year-201 3/national-communication-strategy-action-plan-for-reduction-of-ncd-high-risk-behav iors-in-bangladesh-2014-2016.pdf?sfvrsn=bbcf810c_2

WHO (World Health Organization) (2017a). Health Is a Fundamental Human Right. https://www.who.int/news-room/commentaries/detail/health-is-a-fundamental-human -right\#: :text=\%E2\%80\%9CThe\%20enjoyment $\% 20$ of $\% 20$ the $\% 20$ highest, $\% 2 \mathrm{C} \% 20$ econ omic\%20or\%20social\%20condition\%E2\%80\%9D.\&text=Everyone\%20has\%20the\%20right \%20to,treated\%20with\%20respect\%20and\%20dignity

WHO (World Health Organization) (2017b). Human Rights and Health. https://doi.org/10.4324/9781351155441-3 https://www.who.int/news-room/fact-sheets/detail/human-rights-and-health

WHO (World Health Organization) (2021). Bangladesh. Global Health Workforce Alliance (GHWA).

https://www.who.int/workforcealliance/countries/bgd/en/

WHO (World Health Organization) (n.d.). Primary Health Care. World Health Organization. www.who.int/health-topics/primary-health-care\#tab=tab_1

World Bank Group (2018). Enhancing Opportunities for Clean and Resilient Growth in Urban Bangladesh: Country Environmental Analysis 2018.

https://openknowledge.worldbank.org/handle/10986/30558

World Data Atlas (2018). Bangladesh.

https://knoema.com/atlas/Bangladesh/Health-expenditure-as-a-share-of-GDP

World Data Atlas (n.d.). Bangladesh: Current Expenditure on Health per Capita. https://knoema.com/atlas/Bangladesh/topics/Health/Health-Expenditure/Health-expen diture-per-capita

Worldometer (2021). Bangladesh Population. https://www.worldometers.info/world-population/bangladesh-population/\#: :text=Ba ngladesh $\% 202020 \% 20$ population $\% 20$ is $\% 20$ estimated,(and $\% 20$ dependencies)\%20by\%20po pulation 